Bernhard Hellmich Consultant for: Roche, Speakers bureau: Abbvie, MSD, Roche, Novartis, Pfizer

DOI: 10.1136/annrheumdis-2019-eular.7702

\section{THU0287 ANEURYSM IN BEHÇET'S DISEASE: MANAGEMENT, PROGNOSIS AND MORTALITY}

Berkan Armagan ${ }^{1}$, Ertuğrul Çağıı Bölek ${ }^{1}$, Alper Sarı ${ }^{1}$, Gözde Kübra Yardımcı ${ }^{1}$, Bayram Farisoğulları ${ }^{1}$, Emre Bilgin ${ }^{1}$, Fatma Gonca Eldem², Levent Kılıç ${ }^{1}$, Omer Karadag ${ }^{1}$, Bora Peynircioğlu², Barbaros Erhan Çil ${ }^{2}$, Metin Demircin ${ }^{3}$, Ali Akdoğann ${ }^{1}$, Şule Apraş Bilgen ${ }^{1}$, Ali İhsan Ertenli ${ }^{1}$, Şedat Kiraz ${ }^{1}$, Umut Kalyoncu ${ }^{1}$. ${ }^{1}$ Hacettepe University, Faculty of Medicine, Rheumatology, Ankara, Turkey, ${ }^{2}$ Hacettepe University, Faculty of Medicine, Radiology, Ankara, Turkey; ${ }^{3}$ Hacettepe University, Faculty of Medicine, Cardiovascular Surgery, Ankara, Turkey

Background: Arterial aneurysms are one of the unique features of Behçet's disease (BD). Although arterial aneurysms are relatively rare, they carry risk of rupture and have poor prognosis.

Objectives: To evaluate the medical and interventional therapies and long-term outcomes of BD patients with extracranial arterial aneurysms.

Methods: We retrospectively reviewed the medical records of $441 \mathrm{BD}$ patients according to ISG criteria between 2013 and 2018 at the Hacettepe University Vasculitis Center (HUVAC). We determined 45 BD patients with an arterial aneurysm. Six patients with isolated carotid and/ or cranial arterial aneurysms who were followed by other clinics excluded from the analysis. Overall, $39 \mathrm{BD}$ patients with an extracranial and extra carotidal aneurysm included in the study. Data regarding demographic characteristics, clinical, laboratory and vascular imaging findings, history of medical treatments and outcomes were collected. Vascular intervention of patients were grouped as surgery or endovascular intervention. Radiological response after vascular intervention divided into 3 groups as regression, stable and progression according to radiological evaluation. Regression was defined as a decrease or disappearance of the aneurysm. Stable was defined as no change in the aneurysm diameter. Progression was defined as an increase in diameter of a previous aneurysm or occurrence of a new vascular event. We colligated the stable and regression groups and compared with the progression group. Relapse was defined the progression of the aneurysm which underwent an intervention.

Results: A total of $39 \mathrm{BD}$ patients (Male, 80\%) with an arterial aneurysm were analyzed in this study. Mean age and mean age of diagnosis patients were $40.9 \pm 11.0$ and $29.7 \pm 7.7$ years, respectively. The clinical features of BD was as follows; oral ulcer $100 \%$, genital ulcer $80.6 \%$, acneiform lesion $47.2 \%$, erythema nodosum $33.3 \%$, pathergy positivity $34.5 \%$, arthritis $27.8 \%$, fever $24.3 \%$, uveitis $34.5 \%$, neurological involvement $30.6 \%$ and, gastrointestinal involvement $7.7 \%$. Distribution of arterial aneurysms were $5.1 \%$ subclavian, $5.1 \%$ coronary artery \& cardiac, $38.8 \%$ pulmonary, $10.3 \%$ thoracic aorta, 33.3\% abdominal aorta, $5.1 \%$ renal, $25.6 \%$ iliac and $12.8 \%$ femoral. Induction and maintenance treatments are shown in figure 1. In our cohort, 25 (64\%) patients needed a vascular intervention, including $9(23 \%)$ open operations and $16(41 \%)$ endovascular interventions. Of $7(18 \%)$ patients had to perform an urgent open operation or endovascular intervention but we didn't find any relation between the progression of an aneurysm and urgent intervention. First induction treatment options and prognosis of arterial aneurysms shown in figure 2. At median 71.8 months follow up, 7 (18\%) patient died in the BD aneurysm group. The rate of progression of the aneurysm was $20 \%$ in BD patients with pulmonary artery involvement and $64 \%$ in BD patients with aortic and its branch involvement $(p=0.038)$. In the absence of medical induction treatment, 5 patients had progression, 1 had regression and 1 had no follow-up.

Abstract THU0287 - Table 1.

\begin{tabular}{|c|c|c|}
\hline & $\begin{array}{l}\text { Induction treatment, } \mathrm{n}=39 \\
\text { (\%) }\end{array}$ & $\begin{array}{l}\text { Maintenance treatment*, } n=39 \\
\text { (\%) }\end{array}$ \\
\hline No treatment, $n(\%)$ & $7^{* *}(17,9)$ & $3(7.6)$ \\
\hline Colchicine & $32(82)$ & $15(38.4)$ \\
\hline Medium-high dose steroid, n (\%) & $31(79.4)$ & $11(28.2)$ \\
\hline Cyclophospamide, n (\%) & $18(46.1)$ & $9(23.0)$ \\
\hline Interferon- $\alpha, \mathrm{n}(\%)$ & $21(53.8)$ & $18(46.1)$ \\
\hline Azatiopurine, $\mathrm{n}(\%)$ & $5(12.8)$ & $11(28.2)$ \\
\hline TNFi, $n(\%)$ & $1(2.5)$ & $5(12.8)$ \\
\hline Anticoagulant $\mathbf{n}(\%)$ & $12 * * *(30.7)$ & $7(17.9)$ \\
\hline
\end{tabular}

Abstract THU0287 - Table 2.

Figure 2. Evaluation of response according to vascular intervention and induction treatments *

\begin{tabular}{|l|c|c|c|}
\hline & Stabile/Regression, $\mathbf{n = 1 8}$ & Progression, $\mathbf{n = 1 8}$ & $\mathbf{p}$ \\
\hline Vascular intervention & $10(43.5)$ & $13(56.5)$ & 0.298 \\
\hline Done, $\mathrm{n=23}(\%)$ & $8(61.5)$ & $5(38.5)$ & \\
\hline Not done, $\mathrm{n=13}(\%)$ & & & \\
\hline Induction treatment & 2 & 1 & \\
\hline Cyc & 10 & 5 & \multirow{2}{*}{0.315} \\
\hline Cyc+IFN- $\boldsymbol{\alpha}$ & 3 & 2 & \\
\hline IFN & 0 & 1 & \\
\hline Anti-TNF & 2 & 3 & \\
\hline Azatiopurine & 1 & 5 & \\
\hline No treatment & 0 & 1 & \\
\hline Only steroid & & & \\
\hline *3 patients have no follow-up data \\
Cyc: Cyclophospamide, IFN: Interferon- $\alpha$
\end{tabular}

Conclusion: Arterial aneurysms in BD have poor prognosis and high mortality. Glucocorticoids, cyclophosphamide and interferon- $\alpha$ are the most preferred treatments for induction and maintenance therapy for aneurysm of the BD. Approximately $2 / 3$ of the patients required a vascular intervention. Clinical and radiological progression was more prominent in the aorta and its branches. As expected, there is more progression in interventional procedures without medical treatment.

Disclosure of Interests: Berkan-Armagan: None declared, Ertuğrul Çağrı Bölek: None declared, Alper Sarı: None declared, Gözde Kübra Yardımcı: None declared, Bayram Farisoğulları: None declared, Emre Bilgin: None declared, Fatma Gonca Eldem: None declared, Levent Kılıç: None declared, Omer Karadag: None declared, Bora Peynircioğlu: None declared, Barbaros Erhan Çil: None declared, Metin Demircin: None declared, Ali Akdoğan: None declared, Şule Apraş Bilgen: None declared, Ali İhsan Ertenli: None declared, Sedat Kiraz: None declared, Umut Kalyoncu Grant/research support from: MSD, Roche, UCB, Novartis and Pfizer, Consultant for: MSD, Abbvie, Roche, UCB, Novartis, Pfizer and Abdi Ibrahim, Speakers bureau: MSD, Abbvie, Roche, UCB, Novartis, Pfizer and Abdi Ibrahim

DOI: 10.1136/annrheumdis-2019-eular.5650

\section{THU0288 LONG-TERM FOLLOW-UP OF ANTI-IL6-RECEPTOR TOCILIZUMAB IN REFRACTORY UVEITIS IN PATIENTS WITH BEHÇET'S DISEASE. MULTICENTER STUDY OF 14 PATIENTS IN CLINICAL PRACTICE}

Belén Atienza-Mateo, José Luis Martín-Varillas, Vanesa Calvo-Río, Rosalía Demetrio-Pablo, Natalia Palmou-Fontana, J. Loricera, Emma Beltrán, Marisa Hernández-Garfella, Lucía Martinez-Costa, Elia Valls-Pascual, Antonio Atanes-Sandoval, Miguel Cordero-Coma, Joan Miquel Nolla,

Carmen Carrasco-Cubero, Julio Sánchez, Santos Castañeda, Lara

Sánchez Bilbao, Iñigo González-Mazón, Monica Calderón-Goercke, D. PrietoPeña, Miguel Á. González-Gay, Ricardo Blanco. Reference hospitals,

Rheumatology and Ophthalmology, Santander, Barcelona, Valencia, León, A Coruña, Madrid, Spain

Background: Ocular involvement in Behçet's disease (BD) is a potential severe and disabling complication. Anti-TNF- $\alpha$ agents have shown an improvement of visual outcome in BD-related uveitis refractory to conventional immunosuppressive (IS) drugs. However, these drugs do not achieve control of intraocular inflammation in all patients or are not well tolerated. Tocilizumab (TCZ) has shown efficacy in different refractory ocular inflammatory diseases.

Objectives: To assess the efficacy of long-term therapy with TCZ in refractory uveitis associated to extraocular manifestations (EOM) due to BD.

Methods: Multicenter study of patients with BD refractory to standard systemic treatment.

Results: We followed up 14 patients (9 men/5 women) (26 affected eyes); mean age $40.8 \pm 19.5$ years. Pattern of ocular involvement: panuveitis (10; 4 with retinal vasculitis), anterior (3) and posterior (1) uveitis; 8 recurrent and 6 chronic; 9 with cystoid macular edema. At TCZ onset the following EOM were present: oral and/or genital ulcers (10), arthritis (6), folliculitis/pseudofolliculitis (6), erythema nodosum (3), livedo reticularis (1), intestinal affection (1) and neurological involvement (3).

Before TCZ, they had received corticosteroids (13 intraocular, 12 oral and 12 iv), conventional IS drugs and biologic agents: methotrexate (11), cyclosporine (8), azathioprine (10), colchicine (1), cyclophosphamide (2), mycophenolate mofetil (1), adalimumab (10), infliximab (6), golimumab (3), canakinumab (1), or etanercept (1). TCZ was used in monotherapy (7) or 